\title{
UPAYA PPENINGKATAN KETERAMPILAN MENGHITUNG PECAHAN SENILAI MENGGUNAKAN MEDIA PUZZLE
}

\author{
Nisem \\ SD Negeri Mangunan Sleman \\ nisem.sem12@gmail.com
}

\begin{abstract}
Abstrak
Berdasarkan hasil ulangan harian menunjukkan bahwa siswa kelas IV SDN Mangunan belum tuntas pada materi pecahan senilai disebabkan beberapa faktor. Penelitian tindakan kelas berjudul Upaya Peningkatan Keterampilan Menghitung Pecahan Senilai Menggunakan Media Puzzle di Kelas IV SDN Mangunan Sleman bertujuan untuk meningkatan keterampilan menghitung pecahan senilai di kelas IV SDN Mangunan Caturharjo Sleman. Penelitian ini menggunakan metode penelitian tindakan kelas selama dua siklus dan masingmasing siklus berlangsung selama dua pertemuan. Penelitian ini menilai peningkatan keaktifan, ketermpilan dan prestasi siswa sebagai data utama. Setiap akhir pertemuan, siswa dinilai kemampuannya mengerjakan soal. Pada akhir siklus satu terjadi peningkatan rata-rata kelas sebesar 42,22 menjadi 69,44. Hasil siklus satu belum memenuhi indikator keberhasilan yang ditentukan karena belum mencapai $\geq 75 \%$ dari jumlah siswa yang mengalami ketuntasan. Siklus kedua menunjukkan hasil peningkatan rata-rata kelas sebesar 69,44 menjadi 81,67 Sehingga bisa disimpulkan bahwa penggunaan media puzzle pecahan dari bahan kardus bekas ini mampu meningkatkan ketrampilan menghitung pecahan senilai pada siswa kelas IV SDN Mangunan.
\end{abstract}

Kata kunci : Puzzle, ketrampilan, menghitung, pecahan senilai.

\section{PENDAHULUAN}

Kondisi pada usia sekolah dasar merupakan usia yang memiliki peluang untuk mengembangkan berbagai potensi yang dimiliki anak. Pada kondisi tersebut pola pertumbuhan dan perkembangannya, baik perkembangan fisik, sosial, emosional maupun kognitif anak sudah berkembang secara optimal.

Permasalahan pembelajaran di kelas muncul sebagai akibat naik turunnya kondisi guru dan siswa. Seorang guru dalam melaksanakan pembelajaran seringkali dihadapkan pada masalah-masalah yang berkaitan dengan kesulitan belajar pada peserta didiknya. Rendahnya hasil belajar siswa disebabkan oleh beberapa faktor, diantaranya adalah: peserta didik kurang kosentrasi, cenderung 
pasif dalam pembelajaran, serta guru tidak menggunakan media yang menarik, pembelajaran monoton sehingga dapat mengakibatkan kesan matematika itu sulit.

Menurut J Piaget bahwa perkembangan kognitif anak usia SD berada pada tahap operasi konkrit. Maka sangat penting peran orang tua dan guru dalam proses mengembangkan potensi anak. Pada dasarnya anak pada usia sekolah dasar adalah usia yang masih berada pada tahap (learning by doing) belajar sambil bermain (Udoyoso dan Murti, 2018).

Berdasar pendapat di atas peneliti menggunakan Media Puzzle dalam pembelajaran materi menghitung pecahan senilai pada kelas IV SDN Mangunan. Media Puzzle tergolong media visual yang terdiri dari gambar /foto atau potongan-potongan yang akan disusun menjadi sebuah gambar sebagai media, (Sundayana, 2018)

Berdasar latar belakang di atas, permasalahan dalam penelitian ini dirumuskan sebagai berikut: Bagaimanakah peningkatan keterampilan menghitung pecahan senilai di kelas IV SDN Mangunan Caturharjo Sleman menggunakan Media Puzzle? Penelitian ini bertujuan untuk meningkatan keterampilan menghitung pecahan senilai di kelas IV SDN Mangunan Caturharjo Sleman dengan menggunakann media puzle.

\section{Hakekat Mata Pelajaran Matematika di SD}

Konsep-konsep matematika itu abstrak, sedangkah biasanya anak berfikir dari hal yang kongkret menuju hal yang abstrak, oleh karenanya untuk membantu siswa dalam berfikir abstrak tentang matematika diperlukan media pendidikan dan alat peraga. Sesuai dengan tingkat perkembangan anak usia SD yang masih tahap operasional kongkret, pendapat Jean Piaget dalam buku (Herliani dan Madusari, 2018), maka siswa SD dapat menerima konsep matematika yang abstrak melalui benda-benda kongkret sehingga memerlukan manipulasi objek yang lazim digunakan dalam pembelajaran matematika yang disebut alat peraga.

\section{Bilangan Pecahan}


Menurut pendapat Kennedy dalam (Sukayati, 2012), Pecahan merupakan bagian yang berukuran sama dari yang utuh atau keseluruhan. Sebagai contoh 1/2, 2 menunjukkan banyaknya bagian-bagian yang sama dari yang utuh atau keseluruhan dan disebut penyebut; 1 menunjukkan banyaknya bagian yang menjadi perhatian pada saat tertentu dan disebut pembilang.

\section{Keterampilan Menghitung Pecahan Senilai}

Menurut (Sukayati, 2012), Pecahan senilai disebut juga pecahan ekuivalen. Pecahan 1/2, 2/4, 3/6, merupakan pecahan ekuivalen, yang berarti ketiga pecahan tersebut menyatakan bilangan yang sama. Pecahan ekuivalen juga disebut pecahan senilai atau pecahan seharga atau pecahan-pecahan yang sama. Untuk menentukan pecahan yang senilai dapat dilakukan cara sebagai berikut. Kita akan menunjukkan bahwa $1 / 2=2 / 4$ dengan menggunakan tiga lembar kertas bebentuk lingkaran yang kongruen.

\section{Media pembelajaran}

Media pembelajaran meliputi alat secara fisik digunakan untuk menyampaiakan isi materi pengajaran yang antara lain; buku, tape-recorder, kaset, video, kamera film, slide (gambar bingkai), foto, gambar, grafik, telefisi, dan komputer. Dengan kata lain media adalah komponen sumber belajar atau wahana fisik yang mengandung materi instruksional di lingkungan siswa yang dapat merangsang siswa untuk belajar (Sundayana, 2018).

\section{Media Puzzle}

Bertolak pada pembagian macam-macam media pembelajaran menurut beberapa pendapat ahli, maka peneliti mengelompokkan media puzzle ini pada media visual, hal ini sependapat dengan (Sundayana, 2018). Puzzle adalah salah satu jenis mainan edukatif. Sebagaimana mainan balok, mainan puzzle juga merupakan mainan edukasi tertua". Puzzle memiliki jenis yang tak kalah banyak dari jenis mainan lainnya. Bahannya beraneka macam seperti karton, kardus, spon, gabus, logam, dan kayu. Puzzle dapat berupa jigsaw atau bentuk tiga 
dimensi, menganut azas potongan homogen ataupun acak, biasanya berupa kepingan besar atau kecil atau gabungan keduanya, dapat berupa gambar yang dipecah atau komponen yang digabungkan, serta dapat pula berupa yang disusun pada landasan/bingkai tertentu atau harus dirakit menjadi bentuk tertentu seperti woodcraft.

Berdasarkan pengertian puzzle tersebut dapat peneliti simpulkan bahwa media puzzle ini adalah media pembelajaran edukatif berupa potongan homogen ataupun acak yang memuat gambar/lukisan letak suatu wilayah atau unsur-unsur yang ada di dalamnya, berupa gambar yang dipecah menjadi komponen yang digabungkan. Setiap media pembelajaran memiliki kelebihan dan kekurangan masing-masing, hanya saja guru seharusnya dapat meminimalisir segala kekurangan media pembelajaran yang digunakan berdasarkan pertimbangan pertimbangan yang disesuaikan dengan materi pembelajaran. Meskipun tidak ada yang sempurna, namun guru semaksimal mungkin menggunakan media yang paling efektif untuk digunakan. Sama halnya dengan media puzzle yang akan gunakan, disesuaikan dengan kondisi siswa serta materi pembelajaran yang terkait.

Menurut Maysky Mary dalam (Sundayana, 2018) sisi edukasi mainan jenis puzzle berfungsi untuk: a). melatih konsentrasi, ketelitian dan kesabaran; b). memperkuat daya ingat; c). mengenalkan anak pada sistim dan konsep hubungan; d). dengan memilih gambar/bentuk, dapat melatih anak untuk berpikir matematis (menggunakan otak kirinya).

Berdasarkan kelebihan media puzzle, dapat peneliti simpulkan bahwa media ini sesuai dengan tingkat efektivitas media pembelajaran, maka dari itu diharapkan tujuan pembelajaran dapat tercapai dengan meminimalisir sisi negatif media puzzle. Sehingga tujuan pembelajaran dapat tercapai.

Ide dasar pada media ini adalah peneliti melihat anak senang bermain puzzle dan melihat kertas-kertas kardus bekas yang ada di lingkungan. Peneliti mengajak peserta didik untuk mengumpulkan dan memanfaatkan barang-barang bekas dan bahan lainnya untuk dijadikan puzzle pecahan. Langkah pembuatannya adalah: 


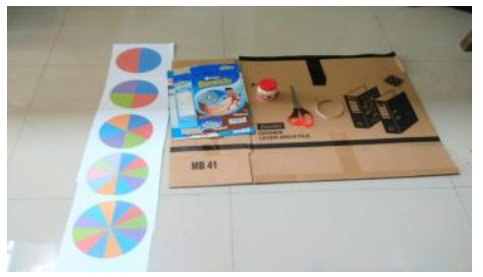

1. Siapkan bahan dan potong lingkaran pecahan

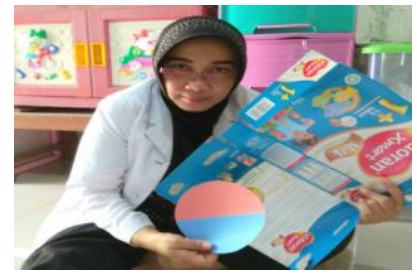

2. Potong dan tempelkan hasil potongan ( langkah no 1) pada karton susu atau sejeninya

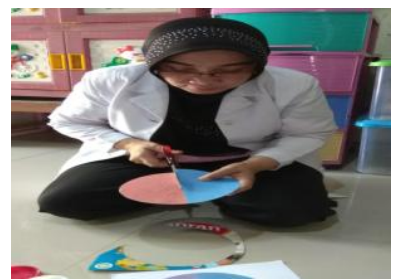

3.Hasil langkah ke 2 digunting sesuai nilai pecahan untuk menjadi kepingan pecahan dan kepingan diberi perekat dibelakangya.

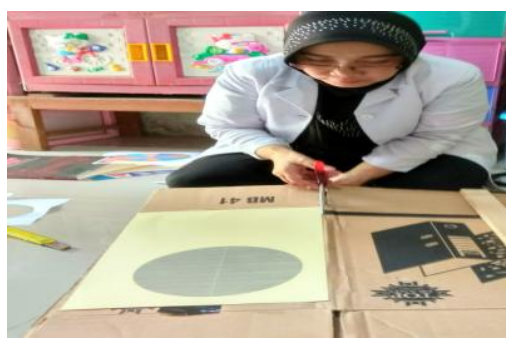

4. Gunting kardus sesuai ukuran kertas lingkaran pecahan

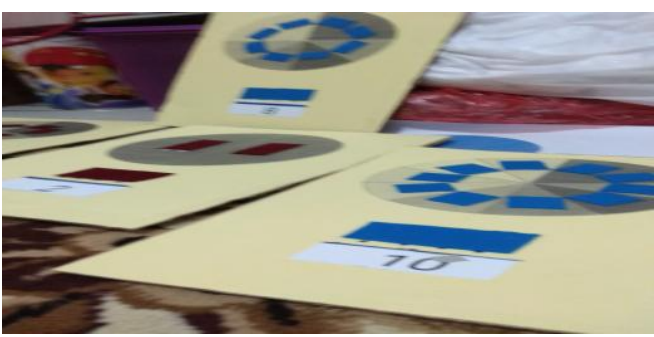

5. Lingkaran pecahan sudah di tempel perekat dan siap untuk digunakan ditempeli kepingan-kepingan puzzle ( seperti hasil langkah 3).

Catatan;

Angka pecahan juga berupa kepingan puzzle angka pembilang dan penyebut yang di ambil dari bekas kalender

\section{Catatan:}

Semua bahan perekat adalah limbah/ karpet/kain planel bekas dan angka sebagai pembilang adalah potongan angka pada kalendeer bekas 


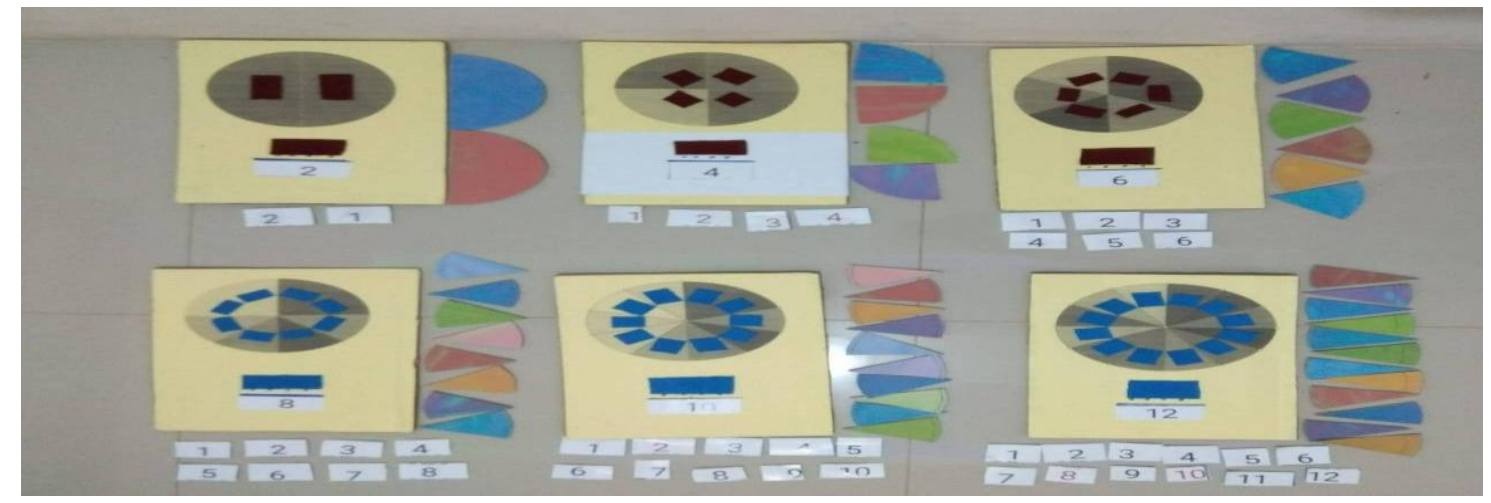

Gambar media puzzle pecahan jadi

Langkah penggunaan media puzzle
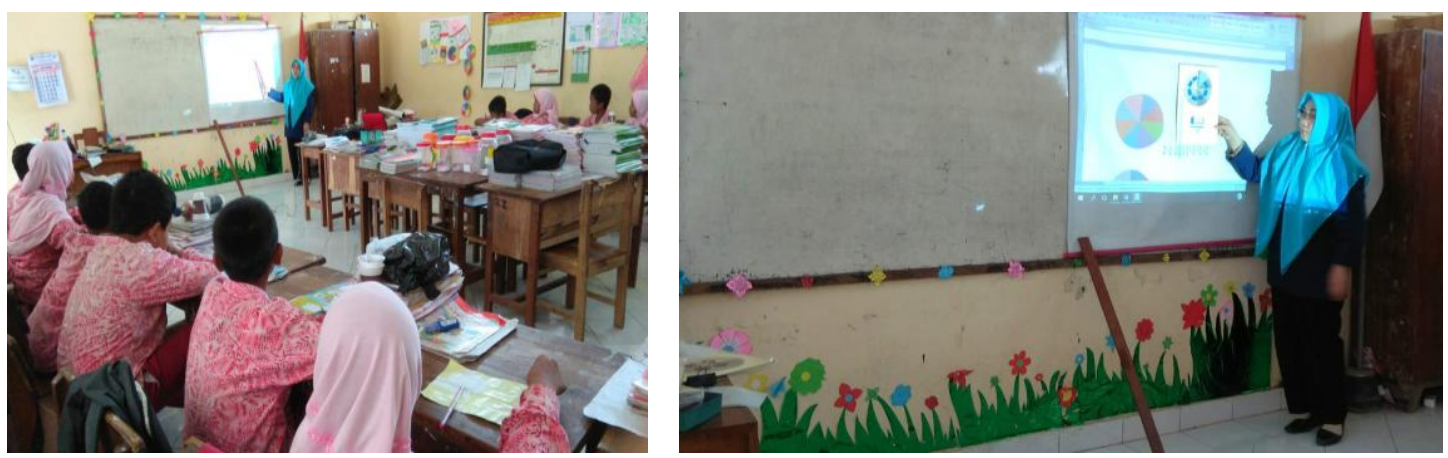

1. Guru menjelaskan tujuan pembelajaran dan materi secara klasikal
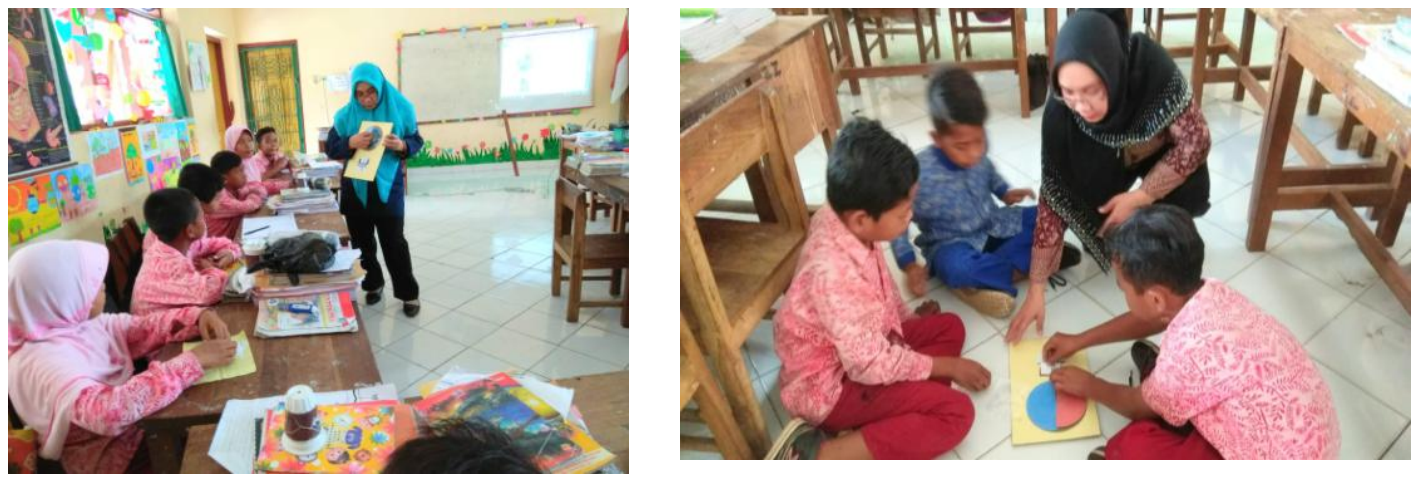

2. Pembimbingan secara kelompok dalam bermain puzzle
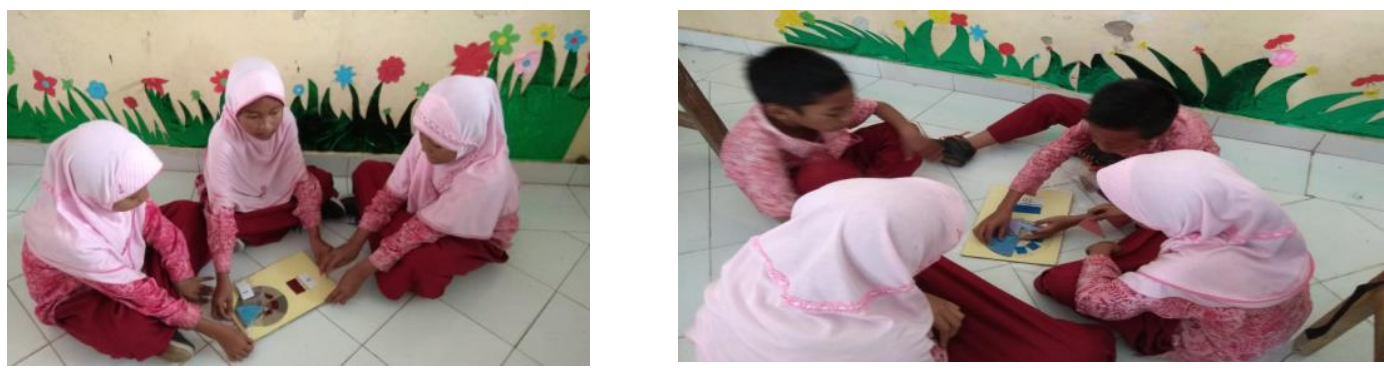
3. Siswa bermain puzzle mandiri dengan kelompok kecilnya

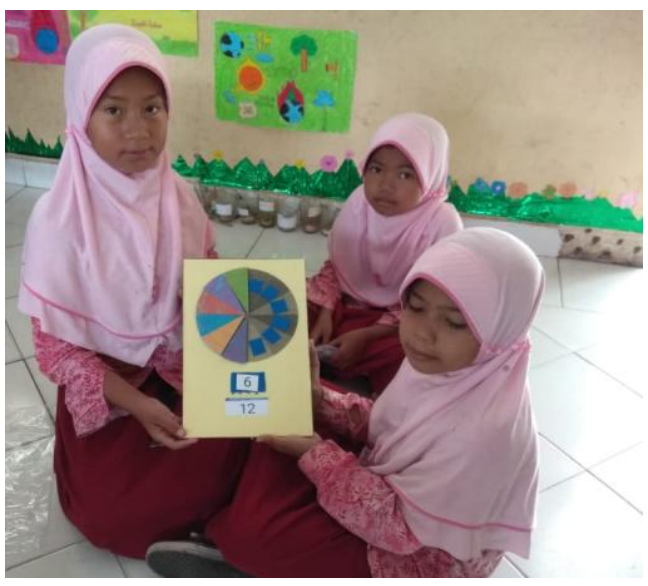

4. Presentasi di kelompok kecil

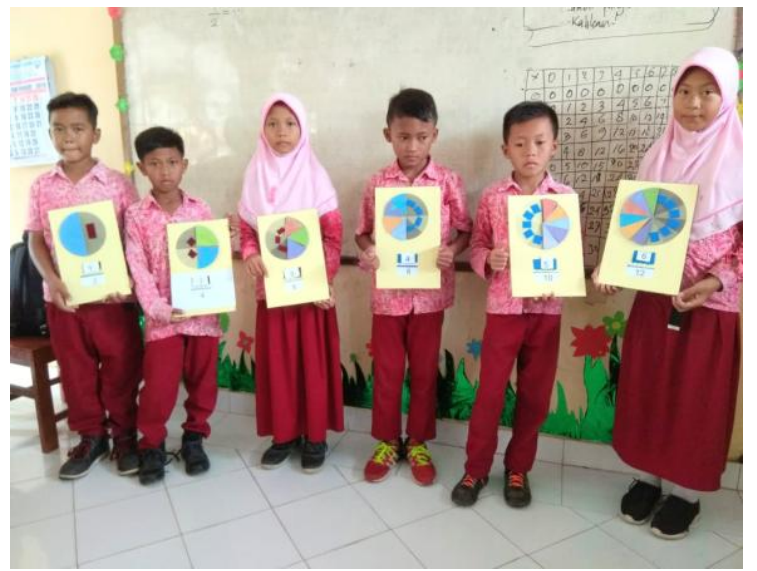

5. Presentasi hasil urutan pecahan senilai di depan kelas diwakili satu anggota perkelompok

\section{METODE}

Peneliti menggunakan desain penelitian tindakan kelas (PTK) yang dikemukakan oleh Kemmis dan Mc Taggart dengan desain putaran spiral yang dikutip dari (Widayati, 2016), dalam masing-masing siklus terdapat empat komponen pokok perencanaan, tindakan, observasi, dan refleksi, dengan tahapan penelitian tindakan kelas sebagai berikut:

\section{Tahap Refleksi Awal}

Bertujuan utuk mengetahui kondisi awal peserta didik kelas IV SDN Mangunan.

\section{Tahap Perencanaan}

Tahap ini adalah mempersiapkan perangkat pembelajaran (RPP), media, lembar observasi siswa san guru.

\section{Tahap Tindakan}

Langkah pelaksanaan tindakan dalam bentuk proses pembelajaran dengan menggunakan perangkat-perangkat pendukung pembelajaran (lembar tugas siswa, media, dan alat evaluasi). Peneliti menggunakan lembar observasi yang digunakan untuk mengamati aktivitas belajar siswa pada saat diberi 
tindakan yang akan digunakan sebagai umpan balik untuk menentukan langkah selanjutnya.

\section{Tahap Observasi}

Observasi berfungsi untuk mendokumentasikan kegiatan yang sedang berlangsung. Pada langkah ini peniliti meminta teman sejawat menjadi observer atau pengamat untuk mendokumentasikan tindakan yang terkait proses pembelajaran serta mengisi lembar observasi yang telah disiapkan.

5. Tahap Refleksi

Refleksi merupakan analisis hasil pengamatan dan evaluasi dari tahap-tahap dalam siklus. Tujuan refleksi dalam penelitian tindakan digunakan untuk memperoleh keterangan tentang seberapa jauh pencapaian dari tindakan yang telah dilakukan.

Subjek penelituan adalah siswa kelas IV SDN Mangunan yang berjumlah 18 peserta didik yang terdiri dari 11 laki-laki dan 6 perempuan pada semester I tahun ajaran 2018/2019 yang berlangsung dari bulan September sampai bulan November 2018.

Teknik pengumpulan data yang akan dipergunakan dalam penelitian ini adalah :

Observasi,tes, dan catatan lapangan.

Konsep penilaian keterampilan dimaksudkan untuk mengetahui penguasaan pengetahuan peserta didik dapat digunakan untuk mengenal dan menyelesaikan masalah dalam kehidupan sesungguhnya atau dunia nyata, sedangkan penilaian pengetahuan dilakukan dengan cara mengukur penguasaan peserta didik yang mencakup pengetahuan faktual, konseptual, dan prosedural dalam berbagai tingkatan berfikir (Latip, 2018). Berdasar hal tersebut Instrumen yang digunakan dalam penelitian ini adalah lembar observasi dan tes. Tes yang digunakan adalah tes tertulis untuk mengetahui keaktifan siswa dalam mengerjakan soal sebagai data kuantitatif.

Analisis refleksi dilakukan dengan mengkoordinasi data hasil observasi yang diperoleh peneliti dengan kriteria keberhasilan yang telah ditetapkan. 
Dalam penelitian tindakan kelas ini data utama yang digunakan adalah tes tertulis dianalisa secara kuantitatif. Bentuk tes adalah pilihan ganda yang terdiri dari 10 soal, sehingga nilai diperoleh dengan rumus sebagai berikut:

\section{Nilai $=($ Jumlah jawaban benar $x$ 10 $)$}

Data kualitatif berupa nilai kemudian diklasifikasikan secara kualitatif berdasarkan nilai KKM adalah 65. Siswa yang mendapatkan nilai 65 atau lebih, dianggap telah tuntas, sedangkan yang belum mendapatkan nilai 65 dianggap belum tuntas atau tidak tuntas. Ketuntasan klasikal ditetapkan sebesar 75\%, artinya peneliti dikatakan berhasil apabila jumlah siswa yang tuntas (mendapatkan nilai 65 keatas) sekurang-kurangnya $75 \%$ dari jumlah siswa kelas IV SDN Mangunan yaitu 18 siswa.

\section{HASIL DAN PEMBAHASAN}

Berdasarka analisis hasil siklus I dan II terlihat peningkatan, hal ini terjadi karena adanya temuan kekurangan pada siklus I dan diperbaiki pada siklus II. Perbandingan antar siklus adalah sebagai berikut:

\section{Hasil bentuk dan menghitung jumlah pecahan senilai.}

Berdasarkan ulangan bentuk dan menghitung jumlah pecahan senilai menunjukkan peningkatan rata-rata nilai antar siklus. Hasil ulangan operasi hitung pecahan dapat dibandingkan pada tabel 1 dan gambar 1.

Tabel 1. Rekap hasil ulangan operasi hitung pecahan senilai pada pra siklus, siklus

1 dan siklus 2

\begin{tabular}{|c|c|c|c|c|}
\hline \multirow{4}{*}{ No } & \multirow{4}{*}{ Komponen } & \multicolumn{3}{|c|}{ Nilai (KKM 65) } \\
\hline & & Pra Siklus & Siklus I & Siklus II \\
\hline & & Ulangan & Pos tes & Pos tes \\
\hline & & Harian & & \\
\hline 1. & Nilai Rata-rata & 42,2 & 69,44 & 81,67 \\
\hline 2. & Jumlah Siswa tuntas & $2(11,1 \%)$ & $13(83,34 \%)$ & $17(94,44 \%)$ \\
\hline 3. & $\begin{array}{lll}\text { Jumlah siswa tak } \\
\text { tuntas }\end{array}$ & $16(88,8 \%)$ & $5(16,66 \%)$ & $1(5,56 \%)$ \\
\hline
\end{tabular}




\begin{tabular}{lllll}
\hline 4. Jumlah & siswa & $18(100 \%)$ & $18(100 \%)$ & $18(100 \%)$ \\
Semua & & & \\
\hline
\end{tabular}

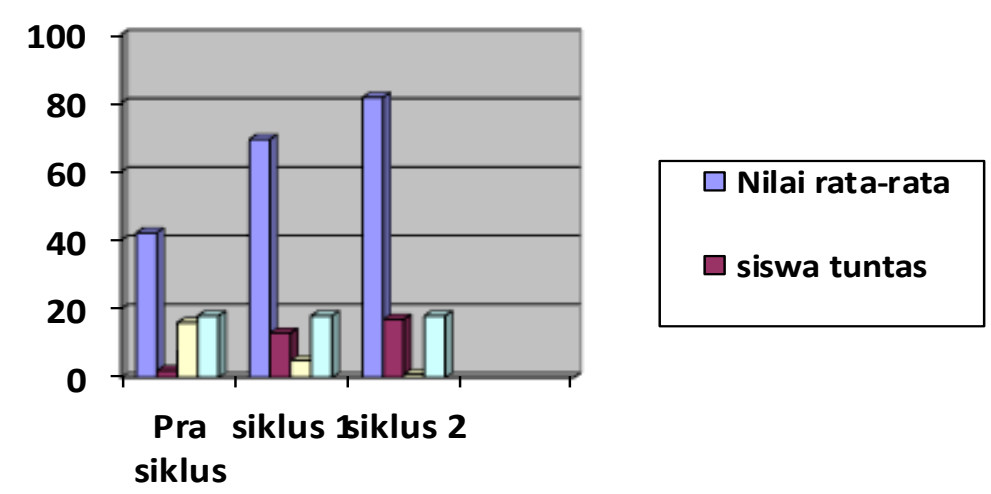

Gambar 1. Rekap hasil ulangan operasi hitung pecahan senilai pada pra siklus, siklus 1 dan siklus 2

Dari tabel 1 dan gambar 1 di atas dapat disimpulkan bahwa pada siklus I diperoleh nilai rata-rata 69,44 sedangkan pada siklus II memperoleh nilai rata-rata 81,67, hal ini terjadi peningkatan. Siswa yang tuntas pada siklus I ada 13 siswa atau 83,34\% dan yang tuntas pada siklus II ada 17 siswa atau 94,44\% dari siklus I ke siklus II terjadi kenaikan 11,10\%. Dengan demikian dapat disimpulkan bahwa penelitian ini berhasil meningkatkan hasil belajar siswa dengan memperoleh ratarata di atas KKM. Siswa yang tidak tuntas mengalami penurunan. Hasil ulangan bentuk dan penghitungan penjumlahan pecahan senilai tersebut dapat dituangkan dalam gambar 2 .
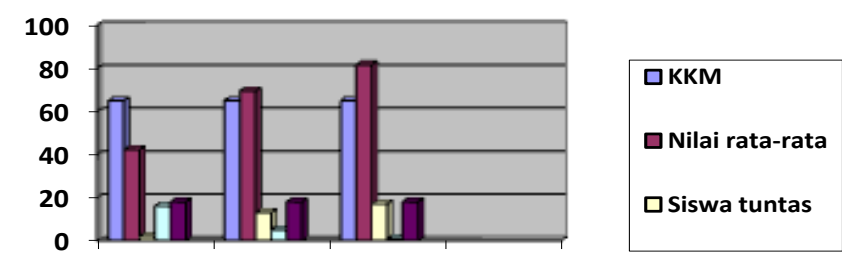

Pra siklus Siklus 1 Siklus 2 
Gambar 2. Grafik analisis hasil ulangan pecahan senilai dari Pra siklus, siklus 1 dan siklus 2

Peningkatan hasil belajar terjadi karena menggunakan media puzzle yang menyenangkan dan kontekstual dengan kehidupan sehari-hari. Berdasarkan hasil pengamatan, dalam proses pembelajaran jika dilaksanakan dengan berkelompok berdiskusi dan senang maka siswa akan lebih mudah menerima materi karena ada respon positif. Proses pembelajaran yang melibatkan siswa berdiskusi dan belajar kelompok untuk memecahkan masalah dan siswa sebaiknya dibiasakan saling belajar dari dan dalam kelompok untuk berbagi pengetahuan dan menentukan fokus belajar.

\section{Hasil Observasi Kelas}

Selain peningkatan hasil belajar, menggunakan media puzzle dapat meningkatkan keaktifan siswa. Perbandingan tingkat keaktifan siswa dapat dilihat pada Tabel 2.

Tabel 2. Rekap Hasil Observasi Kelas Siklus 1 dan 2.

\begin{tabular}{lll}
\hline Diskripsi & Siklus 1 & Siklus 2 \\
\hline Siswa Aktif & 16 & 18 \\
\hline Siswa Pasif & 2 & 18 \\
\hline Persentase(\%)Siswa aktif & $88,9 \%$ & $100 \%$ \\
\hline Persentase(\%) siswa pasif & $11,1 \%$ & $100 \%$ \\
\hline Jumlah Siswa & 18 & 18 \\
\hline
\end{tabular}




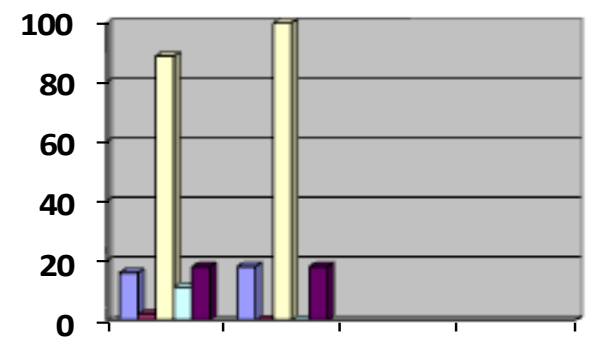

Siklus 1 Siklus 2

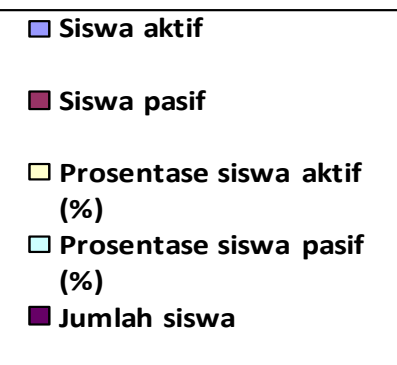

Gambar 3. Grafik Rekap Hasil Observasi Kelas Siklus 1 dan 2

Dari tabel 2 dapat diperoleh data bahwa siswa yang masuk kategori aktif pada siklus I adalah 16 siswa dengan prosentase 88,9\%, sedangkan pada siklus II siswa yang aktif dalam proses pembelajaran ada 18 siswa atau $100 \%$ sehingga siswa yang tidak aktif hanya ada 2 siswa atau $11,1 \%$ dan penyebab dari tidak aktif karena siswa tersebut sedang sakit. Hal ini berarti tingkat keaktifan siswa mengalami peningkatan sebesar $11,10 \%$.

\section{SIMPULAN}

Berdasarkan hasil penelitian dan pembahasan pada bab sebelumnya, dapat ditarik kesimpulan bahwa penggunaan media puzzle dengan memberikan penekanan pada proses keterlibatan siswa secara penuh untuk dapat menemukan materi yang dipelajari dan dihubungkan dengan situasi kehidupan nyata sehingga mendorong siswa untuk dapat menerapkan dalam kehidupan mereka, sangat efektif untuk meningkatkan hasil belajar siswa.

Hasil belajar yang diperoleh pada siklus I yang telah mencapai KKM ada 13 siswa atau 88,34\% dengan rata-rata nilai 69,44. Hasil pada siklus 2 terjadi peningkatan, siswa mencapai KKM 17 siswa dengan nilai rata-rata siswa sebesar 81,67. Presentase siswa yang mencapai KKM pada siklus 2 sebesar 94,55\%. sehingga terjadi peningkatan sebesar $11,10 \%$. 


\section{DAFTAR PUSTAKA}

Herliani, E. dan Madusari, E.A. (2018). Modul Pengembangan Keprofesian Berkelanjutan SD Kelas Tinggi A Kelompok Kompetensi. Jakarta: Kemendikbud Dirjen GTK.

Latip, A. E. (2018). Evaluasi Pembelajaran di SD dan MI Perencanaan dan Pelaksanaan Penilaian Hasil Belajar Autentik. Bandung: PT Remaja Rosdakarya.

Sukayati. (2012). Pembelajaran Pecahan dim Sekolah Dasar. Yogyakarta: CV Empat Pilar Pendidikan.

Sundayana, R. (2018). Media dan Alat Peraga dalam Pembelajaran Matematika. Bandung: Alfabeta.

Udoyoso, B. dan Murti, R.C. (2018). Modul Pengembangan Keprofesian Berkelanjutan. Jakarta: Kemendikbud Dirjen GTK.

Widayati, M. (2016). Jurus Jitu Menyusun PTK Tembus PAK Melejitkam Profesional \& Karier Guru Melalui PTK. Jakarta Selatan: PT. Valua Lidi Impressario. 